\title{
Analysis of Effectiveness of Synchronization Method of Total Physical Response on Content of Worship Material in Implementing English Learning Based on Multimedia for Islamic Kindergarten Schools
}

\author{
Tjatursari WIDIARTIN ${ }^{1}$, Siti AZIZAH ${ }^{2}$, MASLIHAH $^{3}$ \\ ${ }^{1,3}$ Informatics Engineering, ${ }^{2}$ English Education \\ Universitas Wijaya Kusuma \\ Surabaya, Indonesia \\ ${ }^{1}$ widiartin@gmail.com, ${ }^{2}$ sitiazizahazizah81@yahoo.com, ${ }^{3}$ lika.btr@gmail.com
}

\begin{abstract}
Multimedia learning must have a complete material component. The material must be compatible with the target content. This research aims to analyze the effectiveness of synchronization method of Total Physical Response on the content of worship material in producing the material component of multimedia learning. Start by determining the type of worship, then we set the procedures of worship, the stages of worship, and Sentences that must be read for every state of worship. The results are implemented into the Total Physical Response method. From the results of the research can be concluded that combining method of Total Physical Response with content of Worship material will simplify the process of finding the components of multimedia learning materials. Components of multimedia learning will be obtained from the Worship content that are interpreted into the Physical Response, Action Response, and Verbal Response. Each response will produce one or more vocabularies and sentences.
\end{abstract}

Keywords - Effectiveness; Synchronization; Total Physical Response; Response; Physical; Action; Verbal; worship; component; material; multimedia learning

\section{INTRODUCTION}

In today's digital age, the transformation into digital life has already occurred [1]. Using learning media as a tool for teaching and learning process is like a must. Similarly, for English learning, using multimedia media learning will greatly help improve the understanding of the material.

Building a multimedia learning should have a component that is in accordance with the principles of multimedia learning, and should be also compatible with the target of content, namely English.

Using the right method to find the multimedia learning component is also a consideration in the stages of building a multimedia learning.

The process of learning the English language will be more optimal when the learners practice more, and it must be applied in everyday life.
In Islamic-based kindergarten schools, worship lessons are lessons that have a large percentage. Worship must be done regularly, continuously, and istiqomah.

Based on this, in this research will be found multimedia learning component by synchronizing between TPR method in learning English and content worship

\section{LITERATURE REVIEW}

\section{A. Total Physical Response}

The principles and techniques in learning English vary widely.

The implementation of course adapted to the situation of a class and the age of the students, where each has its own advantages.

The method of total physical response is one of the English learning methods that can be used as an alternative to learning English [2].

James Asher is a professor of psychology from the San Jose California University who first introduced the method of total physical response (TPR). Explained that the method of total physical response is a Language learning method that combines the basics of speech and action coordination.

He was explained that the TPR method is implemented as the learning of a Language using the physical movements that used to react to oral feedback in order to reduce barriers and decrease affective of students. The direct pronunciation system in the child will respond to the child's physicality before they begin to produce a verbal response. TPR method is more emphasis on body movement in the learning process, therefore, to further improve the understanding of the material it can be assisted with the media images in accordance with the theme being discussed.

\section{B. the learning of Religious Education}

The learning of religious education covers many things according to the rules and guidance given to each religion. Religious education is basically given to make a person has a 
direction and lifestyle is better, more directed, and more orderly. So there is harmonization in the life of society.

\section{1) Meaning of Worship in Islam}

Shaykh al-Islam Ibn Taymiyyah. He says: "Worship is a term that includes everything that Allah loves and His approval, both speech and deeds, hidden (inner) and visible (physically visible) [3].

In the Islamic religion, all forms of worship basically have been arranged and determined its rule. Muslims basically perform the ordinances of worship referring to the Qur'an and hadith.

\section{2) Types of Worship}

According to the type of action performed, the worship can be divided into three namely: worship of heart, oral worship, and worship body. Examples of worship hearts such as fear and hope to Allah SWT. Examples of oral worship for example do dhikr in the form tahmid, tahlil, and so forth. While the example worship badaniyah for example are perform worship prayer, hajj, and so forth [4]. Regarding the matter of worship prayer, it is known that before the prayer then someone must perform wudhu, as mentioned in the Alqur'an 5:6 [5].

The procedures and order of wudhu are also arranged according to the instructions in the Qur'an[5], that is Q.S 5:6. And Hadith [6][7][8]:

- Book of Hadith of Sahih Al-Bukhari 192 Version of Fathul Bari

- The Hadith of Sahih Al-Bukhari. 159,160 Version of Fathul Bari

- $\quad$ The Book of Hadith Sahih Muslim 226 Syarh Sahih Muslim Version

- Book of hadith Saheeh sunan Abu Daud 102 Baitul Afkar Ad Dauliah Version

The procedure and order of wudhu is as follows:

a) Take a vessel filled with water

b) Calling God's Name: Bismillah, Pouring Water from vessel to palm, hand washing 3 times

c) Insert the hand into the vessel

d) Gargle-gargle

e) Insert the water into the nose and remove it with 3 times of the cuff

f) Insert the hand into the vessel

g) wash face $3 X$

h) Put the hand into the vessel

i) Wash your hands to your elbows twice

j) Wipe the head with one hand, starting from the front to the back, then return it again (towards the front)

k) Inserting his hand into the vessel

l) Wash both feet

\section{Multimedia Learning}

The Definition of a Multimedia Term is basically diverse. However, if viewed from the field of computer science, then multimedia is an application that has multiple modality, namely in the form of text, images, drawing, graphics, animation, sound (including speech), and many more related to interactive things [9]. Understanding of multimedia learning is how to utilize a multimedia in a learning.

\section{RESEARCH METHOD}

\section{A. Algorithm of Algorithm of synchronization between TPR method and worship material}

Stages In synchronizing the Total Physical Response (TPR) method with content worship material as shown in figure 1. The order of steps to be performed are:

a) Determine the type of worship, for example, material samples to be research is the material of wudhu.

b) Setting ordinance of worship based on existing proposition. The material of the ordinance and the order of ablution refers to Alqur'an and saheeh hadeeth

c) Set the order of worship from start to finish

d) synchronization into the TPR method for each order of worship obtained

e) Design components Multimedia learning

f) Perform 1-5 stages until the order of worship is over

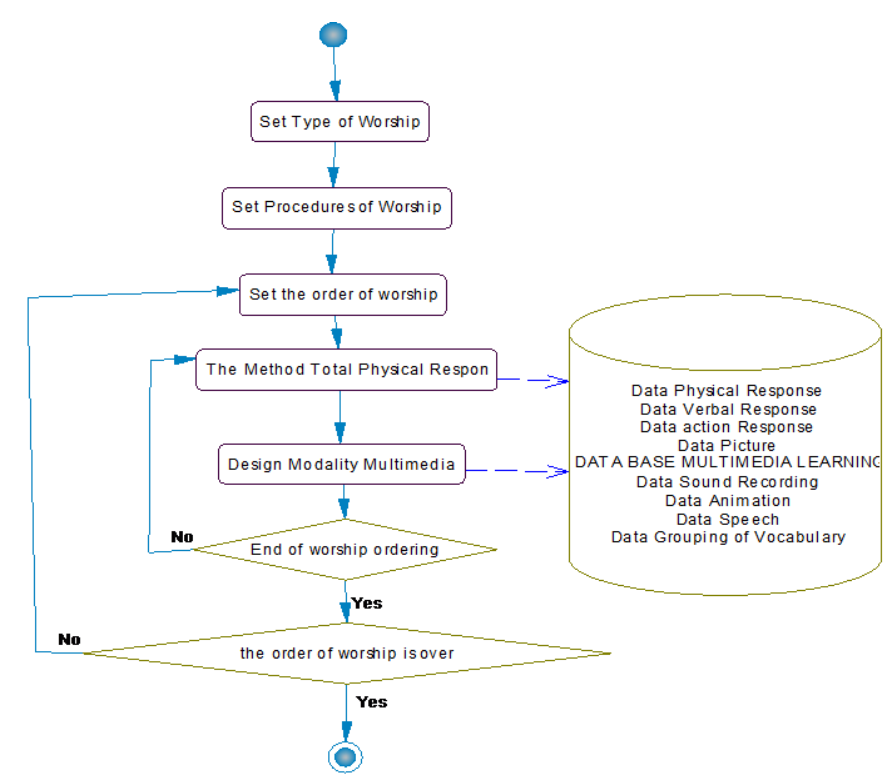

Figure 1. Algorithm of synchronization between TPR method and worship material

\section{B. The Result of synchronization between TPR method and worship material}

Based on the algorithm as shown in figure 1, from the results of the research obtained as much as 13 pillars for wudu worship. The 13 pillars are synchronized into the tpr method. 
The result of synchronization between tpr method and worship material is as follows:

1) Take a vessel filled with water

\begin{tabular}{|c|c|}
\hline Religious learning & English Learning \\
\hline $\begin{array}{l}\text { 1. To know the } \\
\text { procedure of } \\
\text { ablution properly } \\
\text { 2. Know the order of } \\
\text { ablution } \\
\text { 3. Take a vessel filled } \\
\text { with water }\end{array}$ & $\begin{array}{l}\text { 1. Vocabulary learning related to } \\
\text { physical response, ie: hand, finger, } \\
\text { palm } \\
\text { 2. Vocabulary learning related to } \\
\text { action response, ie:Take, Vessel, } \\
\text { filled, Water } \\
\text { 3. Sentence learning: "Mengambil } \\
\text { bejana berisi air" (Take a vessel } \\
\text { filled with water) }\end{array}$ \\
\hline
\end{tabular}

2) Pour water from vessel into palm then wash it three times

\begin{tabular}{|c|c|}
\hline Religious learning & English Learning \\
\hline $\begin{array}{l}\text { To know the } \\
\text { procedure of ablution } \\
\text { properly }\end{array}$ & $\begin{array}{l}\text { 1. Vocabulary learning related to } \\
\text { physical response, ie:hand, } \\
\text { finger, palm }\end{array}$ \\
\hline
\end{tabular}

2. Know the order of 2. Vocabulary learning related to ablution

3. Pour water from vessel into palm then wash it three times action response, ie: pour, water, from, vessel, to, palm, then, wash, three, times

3. Sentence learning: "Menuang air dari bejana ke telapak tangan kemudian basuh sebanyak tiga kali" (Pour water from vessel into palm then wash it three times)

4. Vocabulary learning related to Verbal response, ie: (Saying: Bismillah)

3) Put the hands into the water

\begin{tabular}{|c|c|}
\hline Religious learning & English Learning \\
\hline $\begin{array}{l}\text { 1. To know the } \\
\text { procedure of ablution } \\
\text { properly } \\
\text { 2. Know the order of } \\
\text { ablution } \\
\text { 3. Put the hands into the } \\
\text { water }\end{array}$ & $\begin{array}{l}\text { 1. Vocabulary learning related to } \\
\text { physical response, ie: hand, } \\
\text { finger, palm } \\
\text { 2. Vocabulary learning related to } \\
\text { action response, ie: put, hand, } \\
\text { into,vessel } \\
\text { 3. Sentence learning: "Masukkan } \\
\text { tangan kedalam bejana "(Put the } \\
\text { hands into the water) }\end{array}$ \\
\hline
\end{tabular}

\section{4) Gargle-Gargle}

\section{Religious learning}

1. To know the procedure 1 . Vocabulary learning related to of ablution properly

2. Know the order of mouth, lip, tooth, tongue, hand,

ablution

3. Gargle-Gargle

finger, palm

2. Vocabulary learning related to action response, ie: Gargle

3. Sentence learning: "Berkumurkumur

(Gargle)

5) Put water into the nostrils and spouting water out of the nostrils, By scooping up the water three times the cuff

Religious learning

1. To know the procedure 1. Vocabulary learning related to of ablution properly

2. Know the order of ablution

3. Put water into the 2. nostrils and spouting water out of the nostrils, By scooping up the water three times the cuff

physical response, ie: head, nose, nostril, nose hair, hand, finger, palm

. Vocabulary learning related to action response, ie: filled, water, into, nostril, and, spouting out, again, by, scooping up, three times, cuff

3. Sentence learning: "Memasukkan air ke lobang hidung dan mengeluarkan kembali, dengan menciduk air sebanyak tiga kali cidukan " (Put water into the nostrils and spouting water out of the nostrils, By scooping up the water three times the cuff)

6) Take a vessel filled with water

\begin{tabular}{|l|l|}
\hline Religious learning & English Learning \\
\hline $\begin{array}{l}\text { 1. To know the } \\
\text { procedure of ablution } \\
\text { properly }\end{array}$ & $\begin{array}{l}\text { 1. Vocabulary learning related to } \\
\text { physical response, ie: hand, finger, } \\
\text { palm }\end{array}$ \\
$\begin{array}{l}\text { 2. Know the order of } \\
\text { 2. Vocabulary learning related to } \\
\text { action response, ie:Take, Vessel, } \\
\text { filled, Water } \\
\text { 3. Take a vessel filled } \\
\text { with water }\end{array}$ & $\begin{array}{l}\text { 3. Sentence learning: "Mengambil } \\
\text { bejana berisi air" (Take a vessel } \\
\text { filled with water) }\end{array}$ \\
\hline
\end{tabular}

7) Washing face three times

\begin{tabular}{|c|c|}
\hline Religious learning & English Learning \\
\hline $\begin{array}{l}\text { 1. To know the procedure } \\
\text { of ablution properly } \\
\text { 2. Know the order of } \\
\text { ablution } \\
\text { 3. Washing face three times }\end{array}$ & $\begin{array}{l}\text { 1. Vocabulary learning related to } \\
\text { physical response, ie: face, } \\
\text { Eyes, Eyebrows, Eyelashes, } \\
\text { Nose, Cheeks, Forehead, } \\
\text { Mouth, Lips, Teeth, Tongue, } \\
\text { Hands, Fingers, Palms } \\
\text { 2. Vocabulary learning related to } \\
\text { action response, ie: wash, face, } \\
\text { three times } \\
\text { 3. Sentence learning: "Membasuh } \\
\text { wajah tiga kali" (Washing face }\end{array}$ \\
\hline
\end{tabular}




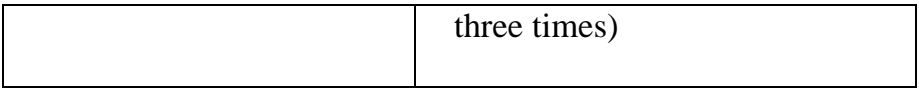

8) Take a vessel filled with water

\begin{tabular}{|l|l|}
\hline Religious learning & \multicolumn{1}{|c|}{ English Learning } \\
\hline $\begin{array}{l}\text { 1. To know the } \\
\text { procedure of } \\
\text { ablution properly }\end{array}$ & $\begin{array}{l}\text { 1. Vocabulary learning related to } \\
\text { physical response, ie: hand, finger, } \\
\text { palm }\end{array}$ \\
$\begin{array}{ll}\text { 2. Know the order of } \\
\text { ablution }\end{array}$ & $\begin{array}{l}\text { Vocabulary learning related to } \\
\text { action response, ie:Take, Vessel, } \\
\text { filled, Water }\end{array}$ \\
$\begin{array}{l}\text { 3. Take a vessel filled } \\
\text { with water }\end{array}$ & $\begin{array}{l}\text { 3. Sentence learning: "Mengambil } \\
\text { bejana berisi air" (Take a vessel } \\
\text { filled with water) }\end{array}$ \\
\hline
\end{tabular}

9) wash your hands up to your elbows twice - twice

\begin{tabular}{|c|c|}
\hline Religious learning & \multicolumn{1}{|c|}{ English Learning } \\
\hline $\begin{array}{l}\text { 1. To know the procedure } \\
\text { of ablution properly }\end{array}$ & $\begin{array}{l}\text { 1. Vocabulary learning related to } \\
\text { physical response, ie: hand, } \\
\text { 2. Know the order of } \\
\text { finger, palm, elbow } \\
\text { ablution }\end{array}$ \\
$\begin{array}{l}\text { 3. wash your hands up to } \\
\text { your elbows twice - } \\
\text { twice }\end{array}$ & $\begin{array}{l}\text { action response, ie: wash, both, } \\
\text { hand, until to, elbow, twice } \\
\text { 3. Sentence learning: "Membasuh } \\
\text { kedua tangan sampai ke siku } \\
\text { dua kali dua kali" (wash your } \\
\text { hands up to your elbows twice) }\end{array}$ \\
\hline
\end{tabular}

10) Take a vessel filled with water

\begin{tabular}{|c|c|}
\hline Religious learning & English Learning \\
\hline $\begin{array}{l}\text { 1. To know the procedure } \\
\text { of ablution properly } \\
\text { 2. Know the order of } \\
\text { ablution } \\
\text { 3. Take a vessel filled with } \\
\text { water }\end{array}$ & $\begin{array}{l}\text { 1. Vocabulary learning related to } \\
\text { physical response, ie: hand, } \\
\text { finger, palm } \\
\text { 2. Vocabulary learning related to } \\
\text { action response, ie:Take, Vessel, } \\
\text { filled, Water } \\
\text { 3. Sentence learning: "Mengambil } \\
\text { bejana berisi air" (Take a vessel } \\
\text { filled with water) }\end{array}$ \\
\hline
\end{tabular}

11) Wiping the head with hand as much as once, starting from the front to the back, then back to front (towards the front)

\begin{tabular}{|c|c|}
\hline \multicolumn{1}{|c|}{ Religious learning } & \multicolumn{2}{|c|}{ English Learning } \\
\hline $\begin{array}{l}\text { 1. To know the procedure of } \\
\text { ablution properly }\end{array}$ & $\begin{array}{l}\text { 1. Vocabulary learning } \\
\text { related to physical }\end{array}$ \\
$\begin{array}{l}\text { 2. Know the order of ablution } \\
\text { response, ie: Head, Hair, }\end{array}$ \\
$\begin{aligned} \text { Wiping the head with hand } \\
\text { as much as once, starting } \\
\text { from the front to the back, } \\
\text { then back to front towards }\end{aligned}$ & $\begin{array}{l}\text { Ears, Forehead, Hands, } \\
\text { 2. Vocabulary } \\
\text { related to action response, }\end{array}$ \\
\hline
\end{tabular}

\begin{tabular}{|l|l|}
\hline \multicolumn{1}{|c|}{ Religious learning } & \multicolumn{1}{|c|}{ English Learning } \\
\hline the front) & ie: Wiping, head, with, \\
hand, as much as, once, \\
starting from, front, back, \\
then, toward learning: \\
3. Sentence \\
"Mengusap kepala dengan \\
tangan satu kali, mulai \\
dari bagian depan ke \\
belakang, lage \\
mengembalikannya lagi \\
(kearah depan)" (Wiping \\
the head with hand as \\
much as once, starting \\
from the front to the back, \\
then back to front (towards \\
the front)) \\
\hline
\end{tabular}

12)

Take a vessel filled with water

\begin{tabular}{|c|c|}
\hline Religious learning & English Learning \\
\hline $\begin{array}{l}\text { 1. To know the procedure } \\
\text { of ablution properly } \\
\text { 2. Know the order of } \\
\text { ablution } \\
\text { 3. Take a vessel filled with } \\
\text { water }\end{array}$ & $\begin{array}{l}\text { 1. Vocabulary learning related to } \\
\text { physical response, ie: hand, } \\
\text { finger, palm } \\
\text { 2. Vocabulary learning related to } \\
\text { action response, ie:Take, Vessel, } \\
\text { filled, Water } \\
\text { 3. Sentence learning: "Mengambil } \\
\text { bejana berisi air" (Take a vessel } \\
\text { filled with water) }\end{array}$ \\
\hline
\end{tabular}

13) Wash both feet to the ankle

\begin{tabular}{|l|c|}
\hline Religious learning & \multicolumn{1}{|c|}{ English Learning } \\
\hline $\begin{array}{l}\text { 1. To know the procedure } \\
\text { of ablution properly }\end{array}$ & $\begin{array}{l}\text { 1. Vocabulary learning related to } \\
\text { physical response, ie: Legs, } \\
\text { ankles, Hands, Fingers, Palms } \\
\text { ablution the order of } \\
\text { 3. Wash both feet to the } \\
\text { ankle }\end{array}$ \\
$\begin{array}{l}\text { Vocabulary learning related to } \\
\text { action response, ie: Wash, both } \\
\text { of, leg, up, ankle } \\
\text { 3. Sentence learning: "Membasuh } \\
\text { kedua kaki sampai mata kaki" } \\
\text { (Wash both feet to the ankle) }\end{array}$ \\
\hline
\end{tabular}

\section{FINDING AND DISCUSSION}

From the results of research that has been done, can be found components of the picture as well as sound that will be used on multimedia learning components that want to be built for learning English, as follows:
a) hand, finger, palm,
b) hand, finger, palm
c) eye, mouth, lip, tooth, tongue, hand, finger, palm 

d) hand, finger, palm
e) head, nose, nostril, nose hair, hand, finger, palm
f) hand, finger, palm

g)face, Eyes, Eyebrows, Eyelashes, Nose, Cheeks, Forehead, Mouth, Lips, Teeth, Tongue, Hands, Fingers, Palms
h) hand, finger, palm
i) hand, finger, palm, elbow
j) hand, finger, palm
k) Head, Hair, Ears, Forehead, Hands
l) hand, finger, palm
m)Legs, ankles, Hands, Fingers, Palms

From the result of synchronization between tpr method with worship material can generated requirement of animation image for multimedia learning which will be built, that is by taking collection of action response, as follows:

\begin{tabular}{|c|c|}
\hline Vocabulary & \multicolumn{1}{|c|}{ Animation } \\
\hline Take, Vessel, filled, Water & $\begin{array}{c}\text { Take a vessel filled with } \\
\text { water }\end{array}$ \\
\hline $\begin{array}{c}\text { pour, water, from, vessel, to, } \\
\text { palm, then, wash, three, times }\end{array}$ & $\begin{array}{c}\text { Pour water from vessel into } \\
\text { palm then wash it three times }\end{array}$ \\
\hline put, hand, into,vessel & Put the hands into the water \\
\hline $\begin{array}{c}\text { Gargle } \\
\text { filled, water, into, nostril, } \\
\text { and, spouting out, again, by, } \\
\text { scooping up, three times, cuff }\end{array}$ & $\begin{array}{l}\text { Put water into the nostrils } \\
\text { and spouting water out of the } \\
\text { nostrils, By scooping up the } \\
\text { water three times the cuff }\end{array}$ \\
\hline $\begin{array}{c}\text { Wash, face, three times } \\
\text { put, hand, into,vessel }\end{array}$ & $\begin{array}{l}\text { Put the hands into the water } \\
\text { wash your hands up to your } \\
\text { elbow, twice }\end{array}$ \\
\hline $\begin{array}{l}\text { Wiping, head, with, hand, as } \\
\text { much as, once, starting from, } \\
\text { front, back, then, toward }\end{array}$ & $\begin{array}{l}\text { Wiping the head with hand } \\
\text { much as once, starting from } \\
\text { the front to the back, then back to } \\
\text { front (towards the front) }\end{array}$ \\
\hline Wash, both of, leg, up, ankle & Wash both feet to the ankle \\
\hline
\end{tabular}

From result of synchronization between tpr method with worship material can generated requirement of animation dialog for multimedia learning that will be built, that is by taking collection of verbal response, as follows:

\section{Saying "Bismillah"}

\section{CONCLUSION}

Synchronizing the Total Physical Response method with worship material is a very effective way of building a multimedia-based english learning. This is because, that are:

1) The Total Physical Response method has a response component in harmony with the matter of worship, where worship is a unity of physical movement and speech

2) each response generated on Total Physical Response method is highly aligned and compatible with the target component on the needs of multimedia learning

\section{REFERENCES}

[1] Subiakto Henry, "Peran Teknologi Informasi dan Komunikasi dalam Perkembangan Industri”, Makalah Keynote Speaker Seminar Nasional Dies Natalis UWKS, 2017

[2] Diane, L., \& Freeman. Techniques and Principles in Language Teaching. Oxford University Publisher, Second Edition, (2008).

[3] Wikipedia, "Ibadat", June 2016, [Online], Available: https://id.wikipedia.org/wiki/Ibadat.

[4] M. Min, "Pengertian Ibadah Dalam Islam dan Macam-Macam Ibadah," 20 Oktober 2016. [Online]. Available: http://www.pelajaran.co.id/2016/20/pengertian-ibadah-dalam-islam-danmacam-macam-ibadah.html. [Diakses 7 Agustus 2017].

[5] Alqur'an

[6] Bari Fathul, "Kitab Hadits Shahih Al Bukhari"

[7] Muslim Syarh Shahih, "Kitab Hadits Shahih Muslim"

[8] Dauliah Baitul Afkar Ad, "Kitab hadits Shahih sunan Abu Daud"

[9] Ze, N. L., Mark, S. D., \& Jhiangchuan, L. Fundamentals of Multimedia. New York: Springer International. (2014). 